\title{
Analysis of The Determination of The Stability of Exchange Rates In Indonesia
}

\author{
Ayu Putri Sumada Br.Ginting \\ Departement of Economics, \\ The State University of Medan, \\ Medan, Indonesia \\ ayu.putrisumada@yahoo.com
}

\author{
Fitrawaty \\ Departement of Economics, \\ The State University of Medan, \\ Medan, Indonesia
}

\author{
Dede Ruslan \\ Departement of Economics, \\ The State University of Medan, \\ Medan, Indonesia
}

\begin{abstract}
The exchange rate is the value of the currency of a country with the value of the currency of other countries, which used to make the international trade. This study aims to analyze the effect of BI Rate, money supply, inflation, foreign exchange tourism, exports and imports on the exchange rate in Indonesia. The analysis uses cointegration equation with Error Correction Model (ECM) method. This paper investigates the relationship between the dependent and independent variables in both the short term and long term. The estimation results show that in the short term, variables that affect the rupiah exchange rate on US \$ in Indonesia are BI interest rate and exports. While in the long run, the independent variable effect on the exchange rate of the rupiah is the BI interest rates, money supply, and export also. Inflation, foreign exchange tourism, and import do not affect rupiah exchange rate either in short or long term. These results show that control the level of interest rates and the money supply as well as encouraging exports have a crucial role in controlling the exchange rate so that the economy will be in a stable condition.
\end{abstract}

Keywords-BI Rate; money supply; inflation; foreign exchange tourism; exports; imports; exchange rate; Error Correction Model (ECM)

\section{INTRODUCTION}

In principle, exchange rates reflect the value of confidence in the country. The exchange rate (exchange rate) is one of the most influential prices in an open economy. It has the substantial effect of other macro variables. The exchange rate is used as a tool to measure the condition of a country's economy. The growth of a stable currency value shows that these countries have relatively good economic conditions (Triyono, 2008:156). The value of currency plays a vital role for the majority of the free-market economy in the world. The distinction used currencies both in countries that import or export will generate a currency exchange rate differences. The difference in the exchange rate of a country currency (exchange rate) is in principle determined by the magnitude of the demand and supply of such currencies (Krugman, 2005).

Since August 14, 1997, Indonesia has adopted a freefloating exchange rate (floating exchange rate) system which means that the rupiah exchange rate will be established and fully devolved to the market mechanism. Since the introduction of a free-floating exchange rate policy until the end of the research period (2015), the rupiah exchange rate fluctuates in the short term and tends to weaken over the long term.

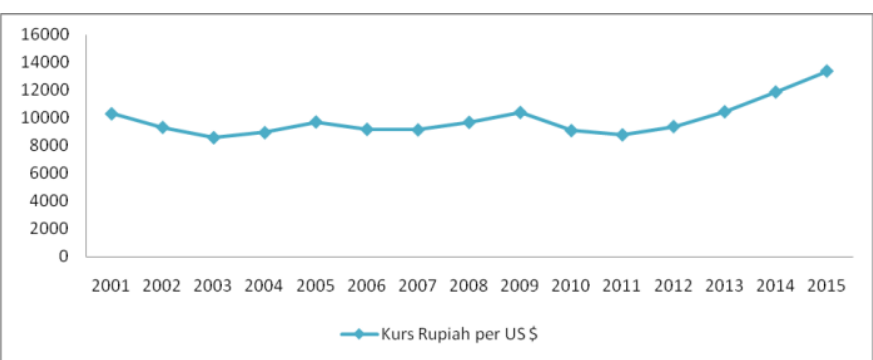

Fig.1. The volatility of the rupiah against the US dollar since the exchange rate system was applied.

Based on the data of the rupiah exchange rate movement against the US dollar shows the fluctuating. In the year 2001, the exchange rate of rupiah of 10299 per US\$ While the year 2014 the exchange rate of rupiah 11878 per US\$ and rupiah exchange rate relatively increased significantly in the year 2015 of 13392 per US\$. The increase is caused by the rise of the money supply from 4.173 .327 to 4.548 .800 . Overall, in the short run the exchange rate continues to fluctuate, but in the long term, it is seen that there is a trend of weakening exchange rate of rupiah currency to US dollar.

The decision embraced an open economy makes the exchange rate is susceptible to the economic fluctuation. An excessively high rate of exchange will lead to a weakening of people's purchasing power on goods and services from other countries. Furthermore, it will have a bad impact on the economy of the country in which many industries and communities depend on resources from other countries.

Review of previous research that the factors that influence the movement of exchange rates (exchange rate) derived from domestic and abroad. These factors include money supply, relative real income, relative prices, inflation differentials, interest rate differentials, and demand and supply of assets in both countries (Kuncoro, 2001:169). Nizar (2012) explains that one of the factors that influence the exchange rate changes is the number of tourists and foreign exchange tourism. 
Through the demand for dollars by foreign tourists will appreciate the exchange rate of rupiah. Parwanti (2011) through its research entitled determinants of rupiah exchange rate against the dollar explains that money supply and inflation can influence the movement of rupiah exchange rate positively, while economic growth has a negative effect on rupiah exchange rate. The result of estimation in this research shows that in the long run, the variable of BI interest rate, money supply, and GDP have significant influence to rupiah exchange rate, while in the short term the variable of GDP of America has a negative effect on rupiah exchange rate. Poornima and Ganeshwari (2016) through his research entitled "An analysis of macroeconomic determinants of exchange rate volatility in India" explains that inflation, trade balance, current account, money supply, and interest together affect exchange rates.

TABLE I. EXCHANGE RATE, BI RATE, MONEY SUPPLY, INFLATION, FOREIGN EXCHANGE TOURISM, EXPORT AND IMPORT IN INDONESIA 2001-2015

\begin{tabular}{|c|c|c|c|c|l|l|}
\hline Years & $\begin{array}{c}\text { Exchange } \\
\text { Rate } \\
\text { (Rp/U\$S) }\end{array}$ & $\begin{array}{c}\text { BI } \\
\text { Rate } \\
(\%)\end{array}$ & $\begin{array}{c}\text { Money } \\
\text { Supply } \\
\text { (billion } \\
\text { rupiahs) }\end{array}$ & $\begin{array}{c}\text { Inflat } \\
\text { ion } \\
(\%)\end{array}$ & $\begin{array}{l}\text { Foreign } \\
\text { Exchange } \\
\text { Tourism } \\
\text { (billion } \\
\text { rupiahs) }\end{array}$ & $\begin{array}{c}\text { Export } \\
\text { (billion } \\
\text { rupiahs) }\end{array}$ \\
\hline 2001 & 10.299 & 17,62 & 844.054 & 12,55 & 5396,27 & $56.320,9$ \\
\hline 2002 & 9.318 & 12,93 & 883.903 & 10,03 & 4305,56 & $57.158,8$ \\
\hline 2003 & 8.573 & 8,31 & 955.692 & 5,16 & 4037,02 & $61.058,2$ \\
\hline 2004 & 8.935 & 7,43 & 1.033 .877 & 6,40 & 4797,88 & $71.584,6$ \\
\hline 2005 & 9.711 & 12,75 & 1.202 .762 & 17,11 & 4521,90 & 85.660 \\
\hline 2006 & 9.167 & 9,75 & 1.382 .493 & 6,60 & 4447,98 & $100.798,6$ \\
\hline 2007 & 9.136 & 8,00 & 1.649 .662 & 6,59 & 5345,98 & $114.100,9$ \\
\hline 2008 & 9.680 & 9,25 & 1.895 .839 & 11,06 & 7347,60 & $137.020,4$ \\
\hline 2009 & 10.398 & 6,50 & 2.141 .384 & 2,78 & 6297,99 & 116.510 \\
\hline 2010 & 9.085 & 6,50 & 2.471 .206 & 6,96 & 7603,45 & $157.779,1$ \\
\hline 2011 & 8.779 & 6,00 & 2.877 .220 & 3,79 & 8554,39 & $203.496,6$ \\
\hline 2012 & 9.380 & 5,75 & 3.307 .508 & 4,30 & 9120,89 & $190.020,3$ \\
\hline 2013 & 10.451 & 7,50 & 3.730 .409 & 8,38 & 10054,15 & $182.551,8$ \\
\hline 2014 & 11.878 & 7,75 & 4.173 .327 & 8,36 & 11166,13 & 175.980 \\
\hline 2015 & 13.392 & 7,50 & 4.548 .800 & 3,35 & 14400 & $150.366,3$ \\
\hline & & & & & \\
\hline
\end{tabular}

Sumber: Statistik Ekonomi dan Keuangan Indonesia, Bank Indonesia

The Quantity Theory of money proposed by Irving Fisher that the price of goods is not only influenced by the amount of money in circulation but also the speed of money circulation. It will result in the price of goods and services increasingly expensive which causes demand for goods and services from abroad down and indirectly will weaken the exchange rate, otherwise, if the speed of money circulation is slower than the price of goods will go down that not directly the value of money goes up. That is, there is a positive relationship between the quantity of money in circulation with the exchange rate. In the table above to see that the money supply in the community continues to experience increased until the year 2015. But Exchange rates do not follow the trend of increase in the money supply but tend to undergo fluctuations.

According to the theory of the relationship of interest rate to the exchange rate is negative, i.e the higher the interest rate will appreciate the exchange rate because it is an attraction for investors to get a higher return on investment. However, the increase in BI interest rate in the year of study did not reflect the strengthening of the rupiah exchange rate. Nurul Ulfa (2016) in his research on the factors that influence the exchange rate explains that the variable of the money supply, the inflation rate, and the interest rate have a significant effect on the movement of Rupiah exchange rate. However Adwin Surja Atmadja (2002) in his research stating that there is no influence between the variable of inflation and interest rates to the rupiah exchange rate, while the variables that affect the exchange rate is just the money supply.

Due to the stability of the exchange rate is one of the sensitive indicators in providing a broad impact on the economy, the study of the variables affecting the rupiah exchange rate becomes very interesting and important to be investigated further. In general, the research was done to the relationship between the independent variable and the dependent variable in the short term and long term. The purpose of this study is to analyze the influence of BI interest rate, inflation, money supply, foreign exchange of tourism, export and import to rupiah exchange rate.

\section{LITERATURE REVIEW}

\section{A. Exchange Rate}

According to Salvatore (1994: 140), the exchange rate is the amount or price of foreign currency. In the monetary approach, the change in each explanatory variable influence to foreign currency exchange rate is as follows: (1) this model estimates that the increase in domestic money supply leads to a proportional increase in domestic prices, and therefore through purchasing power parity will encourage the depreciation of the exchange rate, (2) the relationship between the real exchange rate of foreign money income and relative is negative. The reason, the increase in the income of the domestic demand will cause the excess balance of the money, without a change in the money supply. Can only be fulfilled with the decline in domestic prices. Through the purchasing power parity, the price reduction will lead to an appreciation of the domestic currency, (3) this model predicts that the higher the interest rate differential will make to declining demand for domestic money, which in turn leads to the depreciation of the domestic currency. Therefore, the coefficient of interest rate differentials is positive. 


\section{B. BI Rate}

According to Lipsey, et al. (1995: 22) the interest rate is the price to pay for borrowing money over a certain period and expressed as a percentage of money borrowed. The International Fisher Effect theory (IFE Theory), The purchasing power parity theory explains that the exchange rate will change following the inflation rate between countries, whereas IFE Theory predicts that the exchange rate moves according to the interest rate differential between countries. In The International Fisher Effect theory (IFE Theory), a currency exchange rate will change according to the difference in interest rates between two countries. It results in the average gain of open international money market securities, no greater than the profits derived from domestic money market securities, especially from investors in the country of origin.

\section{Money Supply}

The amount of money available is called the money supply. The government has control over the amount of money supply (Mankiw,2006:79). According to Keynes, request for money based 3 (three) motif that is the transaction, innumerable wakeful and speculation. Speculation is the motive underlying the request money for purposes of daily activity of economic units. The speculative motive for inflation and the exchange rate caused many speculators who suddenly bought foreign currencies resulting in low exchange rates.

\section{Inflation}

According to Boediono, inflation as a tendency of prices to rise in general and continuously. Inflation can be defined as an increase in the price extends to or causes an increase in the bulk of other goods. The Classical theory holds that the money supply is the main determinant of the magnitude of the price level. If the amount of money increases faster than the increase in goods than the value of money will decline, and this equals the price increase. So according to Classical, inflation means too much money in circulation or too much credit compared to the volume of transactions than the medicine is to limit the money supply and credit.

\section{E. Foreign Exchange Tourism}

The effect of changes in foreign exchange of tourism on the exchange rate of currency usually can see through its influence on the availability of foreign exchange in an economy. Thus, if there is an inflow of tourists within a country, will lead the smoothness of foreign exchange which in turn increase the availability (supply) foreign exchange. Conversely, if the outflow of tourists from a country it will reduce foreign exchange reserves. If the foreign exchange supply is greater than the demand, so the foreign exchange price (exchange rate) will decrease.

\section{F. Export and Import}

According to Nachrowi and Usman (2006:443), export is one of the country's foreign exchange resources. The higher export then resulted in the increasing demand for the rupiah so that exchange rate will strengthen/appreciation. According to Mishkin (2008:115), a country's exports increased demand causing its currency strengthened in the long term.

According to Keynes's approach in Joseph et al. (1999) that increased imports will increase the demand for foreign exchange to finance such imports, this in turn, will cause depreciation of the rupiah. According to Nachrowi and Usman (2006: 443), the higher the import will be the higher demand for the US dollar so that the rupiah will depreciate.

\section{METHOD}

This study uses secondary data time series form during 2001-2015. The exchange rate used in this settlement is the rupiah exchange rate against the US dollar that was set by Bank Indonesia. The interest rates used in this research is the $\mathrm{BI}$ interest rate in the form of a percent. The inflation rate in this study used the concept of IHK inflation. The money supply used, i.e., M2 (money in the broad sense) in units of billions of rupiah. The research data were obtained from Badan Pusat Statistik (BPS), Bank Indonesia, and related books and research.

The estimation model used in this research is regression analysis with dynamic model, that is by using error correction model (Error Correction Model/ECM). In an economic context, the dynamic model specification is crucial because it deals with the formation of a model system related to both short-term and long-term time changes. This study uses statistics programs help E-Views version 7

\section{RESULTS AND DISCUSSION}

\section{A. Test Stationeries}

The first thing to do is to examine whether the data is stationary or not. This stationarity test is necessary because a regression analysis should not process if the data used is not stationary and usually if it remains done then the resulting equation is a spurious regression.

\section{1) Test Root-Unit}

To test the behavior of data on research can wear DickeyFuller test (DF). The taking of decision is when the count of a DF variable is greater than the critical value of MacKinnon, means the variable is stationary, and vice versa. Based on table II that not all of the variables used in this study have DF value count greater than the critical value (Mackinnon critical values). In the DF test, the exchange rate variable (EXC) is not significant at $\alpha=1 \%, 5 \%$, and $10 \%$. Since it has not been stationary at zero, it is necessary to test stationarity again by using the integration degree test one. 
TABLE II. TEST RESULT UNIT ROOT

\begin{tabular}{|c|c|c|c|c|c|c|}
\hline \multirow{2}{*}{ Variables } & \multirow{2}{*}{ Value PP } & \multicolumn{3}{|c|}{ Critical Value Mc-Kinnon } & \multirow{2}{*}{ Prob } & Interpretation \\
\cline { 3 - 5 } & & $\mathbf{1 \%}$ & $\mathbf{5 \%}$ & $\mathbf{1 0 \%}$ & & \\
\hline LEXC & 1.304613 & 4.800080 & 3.792272 & 3.342253 & 0.8422 & Non-stationary \\
\hline LBI_RATE & 2.949663 & 4.800080 & 3.791172 & 3.342253 & 0.1783 & Non-stationary \\
\hline LINF & 6.943064 & 4.800080 & 3.791172 & 3.342253 & 0.0004 & Stationary \\
\hline LMS & 3.195855 & 4.800080 & 3.791172 & 3.342253 & 0.1249 & Non-stationary \\
\hline LFET & 7.030267 & 4.800080 & 3.791172 & 3.342253 & 0.0004 & Stationary \\
\hline LEX & 0.219619 & 4.800080 & 3.791172 & 3.342253 & 0.9839 & Non-stationary \\
\hline LIM & 0.934624 & 4.800080 & 3.791172 & 3.342253 & 0.9209 & Non-stationary \\
\hline
\end{tabular}

TABLE III. TEST RESULTS OF THE DEGREE INTEGRATION OF DEGREE ONE

\begin{tabular}{|c|c|c|c|c|c|c|}
\hline \multirow{2}{*}{ Variables } & \multirow{2}{*}{ Value PP } & \multicolumn{3}{|c|}{ Critical Value Mc-Kinnon } & \multirow{2}{*}{ Prob } & Interpretation \\
\cline { 3 - 5 } & & $\mathbf{1 \%}$ & $\mathbf{5 \%}$ & $\mathbf{1 0 \%}$ & & \\
\hline LEXC & 2.662137 & 4.886426 & 3.828975 & 3.362984 & 0.2641 & Non-stationary \\
\hline LBI_RATE & 6.995169 & 4.886426 & 3.828975 & 3.362984 & 0.0005 & Stationary \\
\hline LINF & 12.17632 & 4.886426 & 3.828975 & 3.362984 & 0.0000 & Stationary \\
\hline LMS & 1.451251 & 4.886426 & 3.828975 & 3.362984 & 0.7928 & Non-stationary \\
\hline LFET & 9.439888 & 4.886426 & 3.828975 & 3.362984 & 0.0000 & Stationary \\
\hline LEX & 3.972304 & 4.886426 & 3.828975 & 3.362984 & 0.0402 & Non-stationary \\
\hline LIM & 5.117885 & 4.886426 & 3.828975 & 3.362984 & 0.0071 & Stationary \\
\hline
\end{tabular}

TABLE IV. TEST RESULTS OF THE DEGREE INTEGRATION OF DEGREE TWO

\begin{tabular}{|c|c|c|c|c|c|c|}
\hline \multirow{2}{*}{ Variables } & \multirow{2}{*}{ Value PP } & \multicolumn{3}{|c|}{ Critical Value Mc-Kinnon } & \multirow{2}{*}{ Interpretation } \\
\cline { 3 - 5 } & & $\mathbf{1 \%}$ & $\mathbf{5 \%}$ & $\mathbf{1 0 \%}$ & \\
\hline LEXC & 5.298144 & 4.992279 & 3.875302 & 3.388330 & 0.0066 & Stationary \\
\hline LBI_RATE & 10.59267 & 4.992279 & 3.875302 & 3.388330 & 0.0000 & Stationary \\
\hline LINF & 16.26782 & 4.992279 & 3.875302 & 3.388330 & 0.0001 & Stationary \\
\hline LMS & 7.481795 & 4.992279 & 3.875302 & 3.388330 & 0.0004 & Stationary \\
\hline LFET & 8.761220 & 4.992279 & 3.875302 & 3.388330 & 0.0001 & Stationary \\
\hline LEX & 10.11903 & 4.992279 & 3.875302 & 3.388330 & 0.0000 & Stationary \\
\hline LIM & 14.74838 & 4.992279 & 3.875302 & 3.388330 & 0.0001 & Stationary \\
\hline
\end{tabular}

\section{2) Integration Degree Test}

The integration degree test is a continuation of the unit root test. A test of the degree of integration used to know how data will be stationary. When the data have not been stationary at one, then testing must remain continued until each variable is stationary. To perform this test used DF test. Decisionmaking is when the DF calculates from a variable greater than the critical value of MacKinnon, meaning that the variable is stationary, and vice versa. Based on table III that there are three variables not stationary at the first difference level, as follows the exchange rate variable (EXC), money supply (MS), export (Ex). And four stationary variables are BI interest rate, inflation (INF), foreign tourism exchange (FET), import (IM). Based on that, then again tested Augmented Dickey-Fuller at the second difference level.

Based on Table IV of the Exchange Rate (EXC), BI Rate, Inflation (INF), Money Supply (JUB), Foreign Exchange (DV), Export (Ex), Import (IM). And has been stationary to the same degree, that is, degree one, which is indicated by the DF value of the count greater than its critical value (Mackinnon critical values) at $\alpha=5 \%$. Thus, a cointegration test which requires that the data stationary on the same degree is used.

\section{3) Test Cointegration}

If all the variables pass from the unit root test, then the cointegration test is done to determine the possibility of longterm equilibrium or stability among the variables observed whether or not cointegrated as desired by economic theory. The method used for cointegration test in this research is Engel-Granger Cointegration Test that is first to do the initial regression equation and then get residual tested with PhillipsPerron Test (PP). From the estimation result of Phillips-Perron Test (PP) t-statistic then compared with its critical value. If the statistical value is greater than the critical value, then the variables are taken each cointegrated or have a long-term relationship.

\section{B. Estimation of Error Correction Model (ECM)}

The estimated inflation model using the ECM model aims to find short-term equilibrium or to counteract the short-term imbalance leading to long-term balance. To find out the validity of ECM model, it can be seen from the value of Error 
Correction Term (ECT) whether significant or not. If ECT is significant, then the inflation model specification in Indonesia can be justified by using ECM model. The Error Correction Model (ECM) equation for the short-term period is as follows:

$$
\begin{aligned}
& \mathrm{DL} E X C=0,0225+0,2812 \mathrm{DL} B I_{-} R A T E-0,0586 D L I N F \\
& +0,1942 D L M S+0,0744 D L F E T-0,5994 \mathrm{DLEX}+0,1949 D L I M \\
& -1,1889 \mathrm{ECT}
\end{aligned}
$$

Error Correction Term (ECT) coefficient value is negative (converging) is $-1,1889$ and significant at $\alpha=1 \%$. So it can be concluded that the ECM analysis in this study is valid for use. ECT coefficient value of 1,1889 has the meaning that the difference between the rate of inflation with the balance value of 1,1889 which is adjusted within one year. The equation of Error Correction Model (ECM) for a long period is as follows:

$$
\begin{aligned}
& \mathrm{L} E X C=7,6999+0,3061 \mathrm{~L} B I_{-} R A T E-0,0625 L I N F+ \\
& 0,4264 L M S-0,6693 F E T-0,0472 \mathrm{LEX}+0,2639 L I M
\end{aligned}
$$

\begin{tabular}{|c|c|c|c|}
\hline $\begin{array}{c}\text { Independent } \\
\text { Variables }\end{array}$ & Coefficient & t-Statistic & Prob \\
\hline LBI_RATE & 0,3061 & 3,4443 & 0.0102 \\
\hline LINF & $-0,0625$ & $-1,4821$ & 0,1766 \\
\hline LMS & 0,4264 & 4,2320 & 0.0029 \\
\hline LEX & $-0,0472$ & $-3,2993$ & 0,0109 \\
\hline LFET & $-0,6693$ & $-0,4405$ & 0,6712 \\
\hline LIM & 0,2639 & 1,6679 & 0,1339 \\
\hline $\mathrm{C}$ & 7,6999 & 7,8431 & 0.0001 \\
\hline \multicolumn{2}{|c|}{ R-squared } & \multicolumn{2}{|c|}{0.942918} \\
\hline \multicolumn{2}{|c|}{ Adjusted R-squared } & \multicolumn{2}{|c|}{0.900106} \\
\hline \multicolumn{2}{|c|}{ F-statistic } & \multicolumn{2}{|c|}{22,02477} \\
\hline \multicolumn{2}{|c|}{ Prob(F-statistic) } & \multicolumn{2}{|c|}{0.000145} \\
\hline \multicolumn{2}{|c|}{ Durbin-Watson stat } & \multicolumn{2}{|c|}{1,260724} \\
\hline
\end{tabular}

TABLE V. THE RESULTS OF ESTIMATION OF ECM ON SHORT-TERM

\begin{tabular}{|c|c|c|c|}
\hline $\begin{array}{c}\text { Independent } \\
\text { Variables }\end{array}$ & Coefficient & t-Statistic & Prob \\
\hline DLBI_RATE & 0,2812 & 3,2631 & 0.0172 \\
\hline DLINF & $-0,0586$ & $-1,7408$ & 0,1324 \\
\hline DLMS & 0,1942 & 0,4701 & 0.6549 \\
\hline DLEX & $-0,5994$ & $-2,7351$ & 0,0340 \\
\hline DLFET & 0,0744 & 0,7004 & 0,5099 \\
\hline DLIM & 0,1949 & 1,2195 & 0,2684 \\
\hline ECT & $-1,1889$ & $-4,0125$ & 0.0025 \\
\hline C & 0.0225 & 0,4576 & 0.6633 \\
\hline \multicolumn{3}{|c|}{ Adjusted R-squared } & 0.883890 \\
F-statistic & 0.748429 \\
\hline \multicolumn{2}{|c|}{ Prob(F-statistic) } \\
Durbin-Watson stat & 6,525051 \\
\hline
\end{tabular}

TABLE VI. THE RESULTS OF ESTIMATION OF ECM ON LONG TERM

\section{RESULT AND DISCUSSION}

From the results of simultaneous research all independent variables used in this study affect the movement of the rupiah against the US dollar in Indonesia. In the short term and the long term, the prob (F-statistics) is $\leq 5 \%$. But partially, not all variables affect the movement of the rupiah against the US dollar in Indonesia

\section{Relationship of BI Rate to Exchange Rate}

The result of the research shows that the change of BI interest rate has a positive and significant influence on rupiah exchange rate with coefficient value in the short term is 0,2812 and in long-term equal to 0,3061 . This explains that a $1 \%$ increase in the BI rate will shorten the rupiah exchange rate by 0.2812 and in the long run, the rupiah will depreciate by 0.3061 .

In Keynes's theory, it was explained that the relationship of interest rate to the exchange rate is negative, the increase of interest rate over the foreign interest rate will encourage foreign investors to invest their capital in the country with the aim of obtaining a higher return. So, in theory, the higher the interest rate than the rupiah exchange rate will be more appreciated. However, Keynes's theory is not proven in Indonesia throughout the time of this study. It is allegedly due to an increase in interest rates offset by rising inflation. Of course will be a consideration for investors in investing capital.

It is in line with the results of Marini Syafitri's research (2011) which explained that the increase in BI interest rate could lead to a depreciation of the rupiah against the US dollar. Another factor that is expected to cause an interest rate positive effect on the domestic exchange rate is due to the issue of FED interest rate increase. Nurul Haziza et al. (2015) through her research on the factors affecting inflation explains that interest rates are positive to exchange rate because if there is an increase in international interest rate it will cause the rupiah to depreciate as foreign investors will withdraw investment as well as domestic investors will more investment to America so that the flow of funds out from Indonesia so that the exchange rate will depreciate.

\section{Relationship of Inflation to Exchange Rate}

From the research results can be seen that inflation does not have a significant effect on the exchange rate. The number of probabilities in the short term that is equal to 0.1324 and in the long term, the probability value is 0.1766 . It supports Adwin Surja Atmadja's research (2002) entitled "The analysis of the movement of the rupiah against the US dollar after the implementation of free-floating exchange rate system in Indonesia" states that there is no influence between the inflation variable to the rupiah exchange rate.

\section{Relationship of Money Supply to Exchange Rate}

Based on the results of the study it is explained that in the long term, there is positive relationship and significant effect of the money supply against the exchange rate with the coefficient of 0.426468 and the probability value of 0.0029 . It supports the theory of Irving Fisher which states there is a positive relationship between the money supply with the exchange rate.

\section{Relationship of foreign exchange of tourism to Exchange Rate}


From the research results can be seen that there is no significant influence between the variable of foreign exchange tourism against exchange rate during the time of the study, with a short-term probability value of 0.5099 and in the long term probability value of 0.6712 . It explains that the fluctuation of the entry of foreign tourists to Indonesia caused the of tourism devaluation which gave less meaning to the rupiah exchange rate during the study period. It is in line with Adi Lumaksono's research (2012) about The Impact of International Economy of Tourism on the Economy of Indonesia" which states that the exchange of tourism is less meaningful to the exchange rate due to the large amount of tourism incoming foreign exchange is not proportional to the foreign exchange out of tourism the taste of society towards foreign tourism.

\section{Relationship of Export to Exchange Rate}

The result shows that export has negative and significant influence in short and long-term with each probability value equal to 0,0340 in the short term and 0,0109 in long-term. It is in line with Nachrowi and Usman's opinion (2006: 443) which states that one of source the foreign exchange is export. The higher the export, the higher demand for the rupiah so that domestic exchange rate will appreciate. Mishkin (2008:115) explained that the increase of country's export will appreciated the exchange rate in the long term.

\section{Relationship of Import to Exchange Rate}

Based on the results of the research can be seen that the import variables during the study period despite having a positive direction on the exchange rate but did not give a significant influence in the short and long-term with the numbers of each probability value of 0.26840 in the short term and 0.1339 in long-term.

\section{CONCLUSION AND RECOMMENDATIONS}

In the short term, variables that affect the rupiah exchange rate on US dollar in Indonesia are BI interest rate and exports. While in the long term the independent variables affecting the rupiah exchange rate are BI interest rate, money supply and also export. Inflation, foreign exchange of tourism, and import do not affect rupiah exchange rate either in short or long term. The value of Error Correction Term in this research is equal to -1.1889 , giving the meaning that the process of correction toward long-term balance is getting slower.

BI Rate in the short and long term affect the exchange rate, but the direction is positive. It indicates that the government's policy to overcome the rupiah exchange rate through the interest rate is correct but not yet have a significant impact. Moreover, the issue of increase FED interest rate feared would reduce the rupiah exchange rate due to the transfer of foreign assets and capital invested in Indonesia to the United States. Therefore, BI rate as the benchmark interest rate should be able to control the interest rate in every monetary instrument, besides, Bank Indonesia should also be able to cooperate with the government in terms of macro in order to maintain the confidence of foreign investors in the economy in Indonesia so that the rupiah exchange rate will remain stable.
In addition to interest rates, export variables also in the short term and long term have a negative and significant effect on the exchange rate. It is shown that the sensitivity of export rate will affect the exchange rate. For that reason, monetary policy should be done through inflation control and loan interest rate instrument so that through people's business credit and low and stable inflation rate the government can stimulate the economy through export.

\section{References}

[1] Admadja, Adwin Surja. 2002. Analisa Pergerakkan Nilai Tukar Rupiah Terhadap Dollar Amerika Setelah Diterapkannya Kebijakan Nilai Tukar Mengambang Bebas Di Indonesia. Jurnal Akuntansi \& Keuangan Vol. 4, No. 1, Mei 2002: 69 - 78.

[2] Hazizah Nurul, dkk. 2017. Pengaruh JUB, Suku Bunga, Inflasi, Ekspor dan Impor terhadap Nilai Tukar Rupiah atas Dollar Amerika Serikat. eJournal Ekonomi Bisnis dan Akutansi, 2017, Volume IV (1) : 97-103

[3] Iskandarsyah, Noor. 2013. Faktor-faktor Yang Mempengaruhi Pergerakkan Nilai Rupiah : Analisis Model Moneter Dengan Menggunakan Johansen Cointegration dan Error Correction Model. Widyariset, Vol. 16 No.1, April 2013: 39-48.

[4] Krugman. 2005. Ekonomi Internasional Teori dan Kebijakan. Jilid 2. Edisi 5. PT Indeks Kelompok Gramedia.

[5] Kuncoro, Mudrajad. 2001. Manajemen Keuangan Internasional: PengantarEkonomi dan Bisnis Global. Yogyakarta: BPFE-Yogyakarta.

[6] Lipsey, Richard G. 1995. Pengantar Mikroekonomi. Edisi Kesepuluh. Jilid Satu. Binarupa Aksara. Jakarta.

[7] Lumaksono, Adi. Dkk. Dampak Ekonomi Pariwisata Internasional Pada Perekonomian Indonesia.. Forum Pascasarjana Vol. 35 Nomor 1 Januari 2012

[8] Mankiw Gregory, 2006 Pengantar Ekonomi Makro, Edisi Ketiga, Salemba Empat Jakarta

[9] Mishkin, Frederic S.2008. Globalization, Macroeconomic Perfoermance, and Monetary Policy. NBER Working Paper Series

[10] Nachrowi, D Nachrowi dan Usman, Hardius, 2006. Pendekatan Populer dan Praktis Ekonometrika untuk Analisis Ekonomi dan Keuangan, LPFEUI, Jakarta.

[11] Nizar, Muhammad Afdi. 2012. Pengaruh Pariwisata Terhadap Perdagangan Internasional di Indonesia. Kementrian Keuangan Republik Indonesia.

[12] Parwanti, Nety. 2011. Determinan Nilai Tukar Rupiah Terhadap Dollar Amerika Serikat. Skripsi Jurusan Ekonomi Pembangunan Fakultas Ekonomi Universitas Negeri Semarang

[13] Poornima, S. Ganeshwari, M. 2016. An Analysis Of Macro-Economic Determinants Of Exchsnge Rate Volatility in India. International Journal Of Multidiciplinary Research and Modern Education. ISSN 2454-6119, Volume II,Issue II.

[14] Triyono (2008).Analisis Perubahan Kurs Rupiah Terhadap Dollar Amerika.Ekonomi Pembangunan. Vol. 9, No. 2, Desember.

[15] Ulfa, Nurul. 2016. Analisis Variabel Ekonomi Makro Yang Mempengaruhi Volatilitas Nilai Tukar Rupiah Terhadap Dollar Amerika: Aplikasi Model ARCH/GARCH 